\title{
PENGENALAN DAN PENGEMBANGAN E-MODUL BAGI GURU- GURU SMAN 2 PADANG PANJANG
}

\author{
Budhi Oktavia $^{* 1}$, Rahadian Zainul ${ }^{2}$, Guspatni Guspatni ${ }^{3}$ \\ ${ }^{1,2,3,)}$ Staf Pengajar Jurusan Kimia, FMIPA Universitas Negeri Padang, 25131, Indonesia \\ * Correspondence: budhioktavia8@gmail.com; Tel.: +062-823-8820-1924
}

Diterima Oktober 2019, Disetujui November 2019 Dipublikasikan November 2019

\begin{abstract}
This society service was done in regard to request from teachers in SMAN 2 Padang Panjang who wanted to be given training on the development of e-module as one of innovative instructional materials that can be used in learning process and serves as a credit for career promotion as well. The designed e-module consisted of module components and was based on scientific approach suggested by curriculum 2013. E-module had interactive features with pictures, videos, hyperlinks, pop-up windows and interactive quizzes embedded. Data obtained from questionnaire and observation during training show that teachers were interested in e-module and wanted to use it in learning process. Teachers perceived e-module as instructional material having attractive design and one that could ease students to learn anywhere and anytime.
\end{abstract}

Keywords - e-module, innovative instructional material, interactive features, scientific approach

\begin{abstract}
Abstrak -Kegiatan pengabdian masyarakat ini dilakukan atas dasar permintaan guru SMAN 2 Padang Panjang untuk diberi pelatihan tentang pengembangan e-modul sebagai bahan ajar inovatif yang dapat digunakan untuk pembelajaran dan untuk kenaikan pangkat guru. E-modul yang dibuat berisi komponen modul dan didasarkan pada pendekatan saintifik yang disarankan oleh kurikulm 2013. E-modul juga bersifat interaktif dengan adanya gambar, video, hyperlink, pop-up window dan kuis interaktif. Data yang diambil melalui angket dan observasi selama kegiatan menunjukkan bahwa guru tertarik dengan emodul dan ingin menggunakannya dalam pembelajaran. Guru menilai e-modul sebagai bahan ajar yang mempunyai design yang menarik dan dapat memudahkan siswa untuk belajar dimana saja dan kapan saja.
\end{abstract}

Keywords - e-modul, bahan ajar innovatif, fitur interaktif, pendekatan saintifik

This is an open access article distributed under the Creative Commons 4.0 Attribution License, which permits unrestricted use, distribution, and reproduction in any medium, provided the original work is properly cited. (C2017 by author and Universitas Negeri Padang.

\section{Pendahuluan}

Dalam kurikulum 2013, guru dituntut untuk tidak semata-mata menggunakan metoda ceramah, tapi guru dapat menggunakan pendekatan saintifik untuk mendorong siswa aktif menemukan konsep dan mengembangkan pengetahuan, sikap dan keterampilan. Pendekatan saintifik menuntun siswa untuk melakukan kegiatan belajar dalam tahap Mengamati,
Menanya, Mengumpulkan Informasi, Menalar, dan Mengkomunikasikan (tahap 5M) dalam pembelajaran. Tahap 5M ini difasilitasi oleh guru dengan teknik mengajar tertentu sehingga siswa bukan hanya menerima tapi aktif melakukan kegiatan belajar dan menemukan konsep. Model pembelajaran seperti discovery learning, problem-based learning, inquiry-based learning, dan project-based learning adalah model-model 
pembelajaran yang disarankan untuk mengimplementasikan pendekatan saintifik dalam pembelajaran (Mendikbud, 2014). Selain itu, juga disarankan kepada guru untuk menggunakan bahan ajar atau media pembelajaran yang dapat mempermudah siswa memahami materi pelajaran.

Untuk memenuhi tuntutan kurikulum 2013, guru hendaknya mempunyai keterampilan dan kreatifitas dalam memfasilitasi belajar siswa. Sebagai contoh, guru memanfaatkan perkembangan teknologi untuk merancang bahan ajar yang lebih efektif untuk pembelajaran. Selanjutnya, guru menggunakan beragam media agar pembelajaran menjadi bervariasi dan tidak membosankan. Oleh sebab itu, adalah suatu kewajaran bahwa guru juga diwajibkan untuk mengikuti literasi dasar Teknologi Informasi dan Komunikasi (TIK) dalam rangka meningkatkan mutu pendidikan (Kemendiknas, 2010). Literasi TIK dapat digunakan guru untuk mencari bahan dari Internet; menggunakannya TIK itu sendiri sebagai alat bantu, media maupun sistem pembelajaran; dan membuat bahan ajarnya sendiri sehingga dapat disesuaikan dengan strategi pembelajaran dan karakteristik siswanya.

Penggunaan TIK dalam pembelajaran di SMA sudah menjadi suatu keharusan di zaman sekarang ini. Semua mata pelajaran baik bidang IPA, sosial ataupun bahasa memerlukan bantuan TIK untuk menyampaikan pesan pembelajaran kepada siswa. Mata pelajaran IPA terdiri atas kosep-konsep ilmiah yang bersifat abstrak, simbolik, prosedural dan lain sebagainya yang membutuhkan media berupa pemodelan, gambar, video dan animasi agar dapat dipahami. Mata pelajaran sosial menyajikan pengetahuan berupa cuplikan historis, data perekonomian, geografis suatu daerah dan lain sebagainya yang akan lebih efektif diajarkan dengan bantuan media berupa rekaman, pemodelan, gambar ataupun ilustrasi. Mata pelajaran bahasa merupakan pelajaran literasi untuk memahami bacaan, menulis dan mengkominukasikan ide. Mata pelajaran ini juga membutuhkan bantuan TIK agar ilmunya tersampaikan kepada siswa secara efektif.

Sebagai pendidik, guru harus cakap memilih dan menggunakan bahan ajar yang sesuai agar tuntutan siswa untuk dapat mempelajari konsep melalui pendekatan saintifik dapat terpenuhi dalam pembelajaran. Sejalan dengan itu, guru diharapkan untuk menggunakan karya innovatif dalam pembelajaran. Karya innovatif dapat berupa bahan ajar yang memiliki nilai innovasi untuk pembelajaran di sekolah. Karya innovatif ini dapat diperoleh dari sumber-sumber seperti Internet, buku dan toko perlengkapan sekolah. Karya innovatif juga dapat dibuat oleh guru itu sendiri. Pembuatan karya innovatif oleh guru bisa menjadi poin dan termasuk salah satu persyaratan untuk dapat mengajukan kenaikan pangkat dan jabatan fungsional guru (Kemendiknas, 2010).

Banyak bahan ajar innovatif untuk pembelajaran SMA yang bisa diakses di Internet, diambil dari buku ataupun diperoleh di toko. Namun tentu tidak semuanya sesuai dengan tuntutan kurikulum, strategi pembelajaran yang dipilih guru dan karakteristik siswa. Untuk itu guru sebaiknya mampu membuat sendiri bahan ajar innovatif yang dapat memenuhi tuntutan kurikulum dan sesuai dengan strategi pembelajaran pilihan dan karakteristik siswanya. Untuk itu, guru harus mempunyai keterampilan TIK untuk membuat bahan ajarnya sendiri dan mengembangkannya sehingga mempunyai nilai innovatif untuk pembelajaran.

SMAN 2 Padang Panjang adalah salah satu SMA negeri yang bagus di kota Padang Panjang dilihat dari sarana dan prasarana pembelajarannya. Sekolah tersebut mempunyai kelas yang memadai, lapangan yang luas, labor termasuk ruang TIK dan fasilitasnya. Guru-guru yang mengajar di SMAN 2 Padang Panjang juga terbilang baik dilihat dari kompetensi pendidiknya. Para guru terlihat terbuka dan bersemangat untuk memperbaiki kualitas pembelajaran mereka, salah satunya dengan menggunakan bahan ajar yang lebih efektif, bermutu, dan innovatif.

\section{Solusi/Teknologi}

Berdasarkan analisis situasi, permasalahan guru dan kajian teoritis yang telah dikemukakan di atas, maka kami memutuskan bahwa pelatihan untuk meningkatkan kemampuan guru dalam bidang TIK untuk membuat bahan ajar dalam bentuk e-modul perlu diberikan kepada guru. Pelatihan pembuatan e-modul diharapkan dapat 
memberikan keterampilan kepada seluruh guru mata pelajaran di SMAN 2 Padang Panjang untuk membuat sendiri bahan ajar yang innovatif, menarik dan interaktif menggunakan literasi TIK. E-modul yang dibuat diharapkan bisa mendukung proses kognitif pada siswa dalam pembelajaran sesuai dengan tuntutan kurikulum 2013. Keterampilan yang diperoleh guru diharapkan juga dapat berguna bagi guru dalam menunjang tugas professionalnya dimasa yang akan datang.

Adapun materi dan pelatihan yang akan diberikan dalam kegiatan ini adalah (1) karakteristik bahan ajar dan modul, (2) pendekatan saintifik, (3) prinsip pengembangan bahan ajar, (4) e-modul dan software, (5) visual editing, dan (6) video editing. Di akhir kegiatan, guru diharapkan dapat mengumpulkan e-modul yang mengintegrasikan pendekatan saintifik, memuat visual, video atau animasi yang membantu pemahaman konsep, dan sesuai dengan prinsip pengembangan bahan ajar.

Penilaian keberhasilan pelatihan yang kami berikan akan dilakukan kepada e-modul yang dikumpulkan oleh guru, aktivitas guru selama pelatihan, serta persepsi guru terhadap e-modul yang diperoleh menggunakan angket e-modul. Angket e-modul adalah angket tertutup dengan tujuh pilihan jawaban yaitu STS, Sangat Tidak Setuju (1); TS, Tidak Setuju (2); ATS, Agak Tidak Setuju (3); N, Netral (4); AS, Agak setuju (5); S, Setuju (6); SS, Sangat Setuju (7).

Angket yang disebarkan berisi delapan item yang berhubungan dengan design e-modul untuk pembelajaran, efisiensi penggunaan e-modul, dan minat guru untuk menggunakan e-modul (Item angket terdapat pada Tabel 1).

\section{Hasil dan Diskusi}

Kegiatan pelatihan pembuatan e-modul dilaksanakan selama dua hari berturut-turut diikuti dengan konsultasi lanjut dan pengumpulan e-modul pada 2 minggu selanjutnya. Pada hari pertama dilakukan instalasi semua software yang dibutuhkan. Setelah itu diberikan pelatihan tentang video editing dan pembuatan modul menggunakan Word. Pada hari kedua diberikan pelatihan tentang konversi modul dalam bentuk Word ke dalam bentuk e-modul menggunakan software FlipBook Maker dan penggunaan fitur- fitur interaktif dalam FlipBook Maker. Pada kedua kegiatan tersebut guru terlihat sangat tertarik dengan e-modul dan antusias untuk menggunakan dalam pembelajaran. Hal ini terlihat pada data yang diperoleh dengan angket, seperti yang terlihat pada Tabel 1 berikut.

Tabel 1. Persentase respon guru mengenai e-modul

\begin{tabular}{|c|c|c|c|c|}
\hline No & Item Angket & $\% \mathrm{AS}$ & $\% \mathrm{~S}$ & $\% \mathrm{SS}$ \\
\hline 1 & $\begin{array}{l}\text { E-modul mempunyai } \\
\text { tampilan yang menarik } \\
\text { (attractive). }\end{array}$ & 0.00 & 20.83 & 79.17 \\
\hline 2 & $\begin{array}{l}\text { E-modul mempunyai fitur } \\
\text { yang interaktif untuk } \\
\text { pembelajaran. }\end{array}$ & 0.00 & 41.67 & 58.33 \\
\hline 3 & $\begin{array}{l}\text { E-modul mudah digunakan } \\
\text { dalam pembelajaran. }\end{array}$ & 4.17 & 50.00 & 45.83 \\
\hline 4 & $\begin{array}{l}\text { E-modul mempermudah } \\
\text { siswa belajar dimana saja. }\end{array}$ & 0.00 & 33.33 & 66.67 \\
\hline 5 & $\begin{array}{l}\text { E-modul mempermudah } \\
\text { siswa belajar kapan saja. }\end{array}$ & 0.00 & 37.50 & 62.50 \\
\hline 6 & Saya suka dengan e-modul & 0.00 & 50.00 & 50.00 \\
\hline 7 & $\begin{array}{l}\text { Saya ingin menggunakan e- } \\
\text { modul dalam pembelajaran }\end{array}$ & 0.00 & 62.50 & 37.50 \\
\hline 8 & $\begin{array}{l}\text { Saya akan membuat e- } \\
\text { modul }\end{array}$ & 8.33 & 58.33 & 33.33 \\
\hline & saya sendiri & & & \\
\hline
\end{tabular}

Tabel 1 menunjukkan bahwa sebagian besar guru mempunyai persepsi bahwa e-modul mempunyai design yang menarik. Hal ini dikarenakan oleh adanya variasi warna, font style dan layout yang dapat diatur dalam e-modul. Selanjutnya sebagian besar guru mengaangap emodul mempunyai fitur yang interaktif. Sifat interaktif ini tersedia pada fitur hyperlink, pop-up window, dan interactif quiz yang dapat dibuatkan pada e-modul. Guru-guru yang sangat setuju dengan item angket ini kemungkinan besar telah berhasil memasukkan fitur-fitur interaktif diatas ke dalam e-modulnya seperti yang mereka inginkan.

Sebagian besar guru setuju dan sangat setuju bahwa e-modul mudah digunakan dalam pembelajaran. Jika fasilitas seperti ruang TIK, komputer yang berjalan baik, dan LCD infocus tersedia di sekolah, maka pengguanaan e-modul dalam proses pembelajaran tidak akan menjadi 
masalah. Bahkan e-modul dapat digunakan oleh siswa diluar jam pelajaran. Hal ini juga disetujui oleh guru yang terlihat pada item angket nomor 4 dan 5. Penlitian oleh Prastowo (2014) menunjukkan bahwa e-modul dapat meningkatkan kemampuan siswa untuk belajar sendiri. Bahkan e-modul dapat meningkatkan hasil belajar siswa (Febriyana, 2013) dan keterampilan berpikir kritis siswa (Suarsana dan Mahayukti, 2013)

Sebagian besar guru suka dengan e-modul dan ingin menggunakan e-modul dalam pembelajaran. Bahkan sebagian besar guru juga ingin membuat sendiri e-modul untuk pembelajaran mereka. Walaupun membutuhkan keterampilan TIK dan ketekunan dalam merancang e-modul menggunakan komputer, guru terlihat menemukan banyak kelebihan dalam e-modul. Hal ini juga terlihat pada antusiasme guru dalam mengikuti pelatihan dan menyelesaikan e-modul mereka dalam waktu yang telah dilakukan. Selama pelatihan guru menagjukan banyak pertanyaan tentang skill editing visual, input gambar dan video dan skill design lainnya. Guru juga dapat mengumpulkan e-modul yang dibuat pada waktu yang telah ditentukan. Contoh e-modul yang dibuat guru dapat dilihat pada Gambar 1.

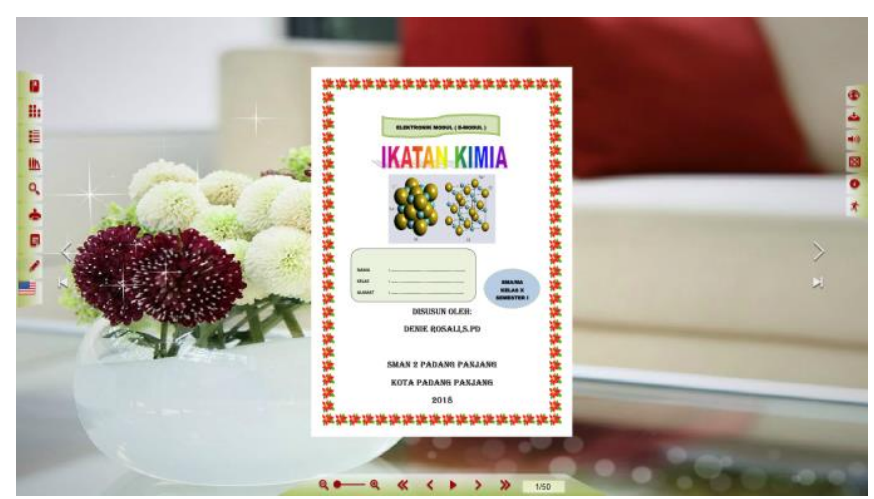

Gambar 1. Contoh e-modul yang dibuat guru SMAN 2 Padang Panjang

\section{Kesimpulan}

Kegiatan pengabdian mengenai pembuatan emodul berbasis pendekatan saintifik telah berhasil dilaksanakan. Guru terlihat antusias selama kegiatan pelatihan yang terbukti dari e-modul yang dikumpulkan pada jadwal yang telah ditetapkan. Guru tertarik dengan e-modul karena e-modul dinilai menarik, interaktif, dan dapat digunakan oleh siswa dimana dan kapan saja.

\section{Ucapan Terima Kasih}

Penulis mengucapkan terimakasih kepada Lembaga Penelitian dan Pengabdian Masyarakat (LP2M) Universitas Negeri Padang, yang telah mendanai penelitian ini melalui Dana DIPA Universitas Negeri Padang Tahun Anggaran 2018 sesuai dengan Surat Keputusan Rektor UNP Nomor SP DIPA-042-01.2400929/2018 Tanggal 5 Desember 2017.

\section{Pustaka}

Febriyana, D. A. 2017. Penerapan E- Modul Berbasis Pembelajaran Kooperatif Tipe Team Game Tournament untuk Meningkatkan Hasil belajar Siswa Pada materi Diklat Konstruksi Bangunan Kelas X TGB SMKN 1 Nganjuk, Jurnal Kajian Pendidikan Teknik Bangunan Vol 2 Nomor 2/JKPTB/17 (2017), 190-196.

Kemendiknas. 2010. Panduan Pengembangan Bahan Ajar Berbasis TIK. Jakarta: Dirjen Manajemen Pendidikan dasar dan Menengah.

Kemendiknas. 2010. Pedoman Kegiatan Pengembangan Keprofesian Berkelanjutan (PKB) Dan Angka Kreditnya. Jakarta: Dirjen Manajemen Pendidikan dasar dan Menengah.

Mendikbud. (2014). Peraturan Mentri Pendidikan Dan Kebudayaan Republik Indonesia Nomor 59 Tahun 2014 Tentang Kurikulum 2013 SMA/MA. Jakarta: Dirjen Menteri Pendidikan Dan Kebudayaan Republik Indonesia.

Prastowo, A. 2011. Panduan Kreatif Membuat Bahan Ajar Inovatif. Yogyakarta: Diva Press. Prinsip dan Teknik Evaluasi Pengajaran

Suarsana I,M. \& Mahayukti, G.A. (2013). Pengembangan E-Modul Berorientasi Pemecahan Masalah Untuk Meningkatkan Keterampilan Berpikir Kritis Mahasiswa. Jurnal Pendidikan Indonesia, 2(2), 270-275. 